\title{
IdeAs
}

Idées d'Amériques

$6 \mid 2015$

Migrer dans les Amériques

\section{Sex, Loyalty, and Betrayal : Migration and the Limits of Patriarchal Privilege}

Sexe, loyauté et trahison: la migration et les limites des privilèges patriarcaux

Sexo, lealtad y traición: Migración y límites del privilegio patriarcal

\section{Deborah Cohen}

\section{OpenEdition}

\section{Journals}

Édition électronique

URL : https://journals.openedition.org/ideas/1295

DOI : $10.4000 /$ ideas. 1295

ISSN : $1950-5701$

Éditeur

Institut des Amériques

Référence électronique

Deborah Cohen, «Sex, Loyalty, and Betrayal : Migration and the Limits of Patriarchal Privilege », IdeAs [En ligne], 6| 2015, mis en ligne le 18 décembre 2015, consulté le 19 octobre 2022. URL : http:// journals.openedition.org/ideas/1295; DOI : https://doi.org/10.4000/ideas.1295

Ce document a été généré automatiquement le 19 octobre 2022.

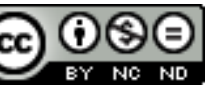

Creative Commons - Attribution - Pas d'Utilisation Commerciale - Pas de Modification 4.0 International - CC BY-NC-ND 4.0

https://creativecommons.org/licenses/by-nc-nd/4.0/ 


\section{Sex, Loyalty, and Betrayal : Migration and the Limits of Patriarchal Privilege}

Sexe, loyauté et trahison : la migration et les limites des privilèges patriarcaux Sexo, lealtad y traición: Migración y límites del privilegio patriarcal

Deborah Cohen

\section{Introduction}

1 One night as my friend Juan Pablo and I left work at a small Chicago restaurant, I asked about the impact of men's extramarital affairs on wives left in Mexico and on their marriages more generally. I had seen much flirtation and evidence of sexual relationships between married migrant cooks, bussers, and dishwashers and their U.S. white co-workers since I had started my ethnographic fieldwork at The Eatery three months before; that evening had been particularly illustrative in this regard. Yet Juan Pablo informed me, matter-of-factly, that the men suffered no consequences for dalliances. "No one talks about what happens in Chicago [outside Chicago]," he explained. "It doesn't count."

2 Juan Pablo's attitude did not strike me as that unusual; it was consistent with understandings and practices of manhood and patriarchal privilege I had already seen in Durango, Mexico, the town of origin for most Eatery men (Cohen, 2011). Still, his assertion piqued my curiosity. Despite his claims of inconsequentiality, I would come to recognize the profound impact of men's affairs: they put in conflict men's ability to act on their sexual privilege, their responsibility to defend family honor, and the need for harmonious inter-migrant relationships. While elsewhere I explore the effects of these affairs on the broader workings of this U.S.-Mexican transnational community (Cohen, in progress), here I focus on the consequences of men's trysts for this Chicago migrant community and the ways men limit their impact. 
3 The dynamics of migrant social relations, ones anchored in family intermarriage and longstanding friendships that had tied men together prior to migration, were reshaped by aspects of men's new lives as migrants. Most men were undocumented, non-English speakers, and unfamiliar, at least initially, with how to get a job or find a place to live. More established migrants provided newcomers with upfront funding to migrate, apartments, connections to employers, and fake documents to secure needed work. That is, established relations butted up against the new constraints of men's lives held and the limitations they brought. Unlike their previous social status as fully adult men, new arrivals found themselves in positions of dependence, relying on the very acquired knowledge and social capital of more established brethren. But longtime migrants gained as well. Not only was the Chicago community, and their position in it, strengthened by additional members, old timers' work and character reputations were bolstered through the labor and clean living of newcomers; moreover, newcomers' success also fostered the viability of the community and contributed to the financial support, and thus stability, of relatives in Mexico, decreasing the weight of earlier migrants' responsibilities. Thus, where previously men's relationships had been organized around adult male independence (in contrast to female dependence), selfreliance, and a more equal reciprocity between male friends and family members, now migrants needed each other.

4 This new interdependence, in turn, threw into question a man's claim to adult manhood and the rights and privileges flowing from it. Manhood, for Durango's popular classes, entailed the fulfillment of economic and social responsibilities to family as head of household. For men with limited resources, however, this claim was always tenuous and migration northward has become imagined as the path to regaining a status undercut by few economic options. ${ }^{1}$ Of importance here is one of manhood's attendant privileges: sexual privilege. All adult males, married or not, were seen to have sexual needs and afforded the right to act on them, with stories of sexual prowess boosting a man's standing vis-à-vis other men. Lest men run sexually amok, privilege's wonton exercise was contained (at least in theory) by a patriarchal code of family honor. Not only did this code establish and confer gendered social norms, hierarchies, rewards, and responsibilities, but men too had a stake in adhering to it: their claims to adult manhood could be threatened from an inability-or unwillingness-to protect family members from physical harm and tarnished reputations.

While brothers-in-law had long cheated on men's sisters, uncles on aunts, fathers on mothers, and friends on loved ones, men's new dependent position in Chicago cast on them the shadow of female dependence, chipping away at a claim on the rights (and responsibilities) men assumed unconditional. By not intervening to stop other men's affairs, even where the wronged party was a close family member, men not just resecured their own right to act on sexual desire, they also prioritized migrant interrelations and the Chicago community over those of family. This implicit consent, then, produced a loyalty that re-sutured the very bonds that affairs put in jeopardy.

Here I show how the patriarchal code of honor that allows male liaisons as expressions of sexual need puts the stability of the migrant community at risk; and the steps migrants take to contain this risk. I use as my fieldsite the restaurant where many of these men worked as the staging ground for my explorations of migrants' infidelities; where I, employed as a waitress, got to know them; and where they met and interacted with the restaurant's college educated, white, female U.S. waitstaff. Most Eatery men 
were between 17 and 49, married-though several were single-and related by blood or marriage or marriage's broader ties (cousins of cousins). For example, Juan Pablo's brothers, David and Luis, as well as a brother-in-law were all living in Chicago and part of The Eatery community. My examination of these migrant-waitstaff relationships is based on almost four years of ethnographic research in Chicago and Durango from 1990-1996 (this article deals only with Chicago).

Even as migrants' tacit acceptance of these relationships enabled community members to act on their sexual desires and exercise male privilege, the interdependence of migrant life required limits on that privilege. While sexual privilege was contained in Durango by men's responsibility to defend their family's honor, in a Chicago community grounded in family ties and intermarriage, it would be kept in check by different means. The community would come to tolerate only those affairs not seen to threaten the health of a marriage. In imposing this limit, affairs did not jeopardize the Chicago social bonds on which all migrants depended for life there. Juan Pablo was right - the affairs didn't count.

What constituted a healthy marriage was fairly broad, however-cheating men only had to demonstrate their bare-bones investment in it. Still, this minimum requirement compelled other migrants to assess the viability of the cheater's conjugal unit, usually a generous assessment that rarely led men to challenge other's affairs or their right to have them. I argue that, in Chicago, the migrant alliances and social webs engendered by marriage and reconfigured north of the border both fostered the ability to act on sexual desire and have extramarital relationships and became the vehicle for containing their destabilizing effects. Only in recognizing this containment can we begin to understand the larger social and cultural dislocations and array of losses that ground unauthorized migration.

\section{Manhood, Patriarchal Codes, and Romantic Relationships in The Eatery}

Until now little research on migration has examined its impact on social and sexual relations. Those scholars, largely anthropologists and from Women Studies, who have conducted nuanced investigations of sexual relationships have examined sexuality within home communities; they have not generally analyzed the ways that migration itself might reconfigure them or particular sexual practices (exceptions being Hirsch J. et al., 2009 ; Gordillo L. M., 2010 ; Minian, in progress). Instead, the focus has often been women's migration and its impact on gender reformation (Hondagneu-Sotelo P., 1994 ; Wilson, 2009 ; Knorr J. and Meier B., 2001), especially in transnational arrangements of care labor (Segura D. and Zavella P., 2007 ; Parreñas R. S., 2001 ; George S., 2005 ; Macdonald C. L., 2011). Those sociological and historical studies that have explored sexuality frequently discuss it in terms of the experience of gays and lesbians and the limits on their inability to migrate (Cantu L., 2009 ; Luibheid E. and Cantu L., 2005). A last line of scholarship, mainly by sociologists, has explored the broad political - as opposed to social - realignments that have occurred in transnational communities (Goldring L. and Krishnamurti K., 2008 ; Smith R. C., 2005). This article tries to weave together the various threads of this literature and build on its strongest aspects. It broadly analyzes the impact of the social - in this case, the social networks and 
relationships important for life in Chicago - on reframing the meaning of and new limits on the sexual.

When I began my fieldwork at The Eatery, I was well aware that restaurants were often spaces of cross-ethnic, -national, and -racial flirtation and interaction, and this one was no exception. As I watched the trajectory of romantic relationships between the migrant men and Eatery women, I began to see how men who challenged patriarchal codes of honor by defiling another migrant's family honor faced no calls to end the affair. By patriarchy, I refer to a social system grounded in kinship, in which certain senior men have privileges and authority over other members, ranked by age, gender, and kin proximity to the ranking patriarch and whose particular forms are culturally and historically specific (Frazier L. J., 2007 ; Kandiyotti D., 1990, 1994, 1999). While the marital couple was a central link in this system, patriarchy created multiple ties of loyalty, of which the conjugal tie is not necessarily the most important. It was also expressed in the gender assignment of responsibilities and realms of authority and in the understandings associated with supposedly innate sexuality (Kandiyotti D., 1990, 1994, 1999). Such notions of innate sexuality we see, for example, in wives' and husbands' naturalization of men's thirst for sex (Mahler S. J., 2001), which confirmed as fact the notion that (most) men would stray from the marriage bed and a set of associated privileges that permitted them to do so with few consequences. These beliefs, then, should be seen as part and parcel of the patriarchal code of family honor.

Still, this was a "modern" patriarchy, one whose logic enabled husbands and wives to understand theirs as companionate marriages (Hirsch J. S., 2003). In this narrative of love and romance, marriage unites two individuals - not families; and it becomes the place for sexual fulfillment, putting the couple above all other relationships (Hirsch J. S., 2003). Despite this "modern" veneer, in practice, the couple sutures families together, creating elaborate social webs of extended family and friends. These webs, which migrants' affairs potentially undercut, were the very axis around which the Chicago migrant community was built and survived. ${ }^{2}$ To minimize such threats to migrant interdependence, sexual privilege needed to be contained. ${ }^{3}$

12 The relationship between waitress Greenlee and pizzamaker Carlos is an example of how threats to the community were contained. The two had decided to keep their relationship a secret because Carlos was married to Marissa - Juan Pablo's and David's sister. One Saturday night after work, Carlos, Greenlee, and I, along with other Eatery employees, decided to go out dancing. Once inside the crowded club, established couples headed to the floor. Within minutes Greenlee and Carlos maneuvered the possibility of a dance. Although he would ask other women to dance and Greenlee partnered with other men, they spent a significant time together, the first time they had done so. When Greenlee and I were returning from the bathroom, we passed Juan Pablo's brother David. He glared at her and said, "you can sleep with him here, but he's never going to leave [his wife]. She's beautiful...thinner, too." He paused, put down his empty glass, and walked over to rejoin his friends.

David's anger exposes a tension between Carlos's right to sexual liaisons outside the conjugal unit, which patriarchy affords, and the need in Chicago for stable migrant bonds. His admonishment of Greenlee, and not his brother-in-law, suggests whom he considered culpable and who was just acting on his so-called sexual nature. In reminding her of the primacy of Carlos's marriage, he appealed for constraint of her emotions, of her investment in the relationship. Still, in chastising her, David partially 
and temporarily sanctioned this officially unsanctioned relationship; he never questioned Carlos's right to a non-marital relationship or his investment in his marriage, which the latter demonstrated with weekly phone calls to his wife, financial support, and occasional trips home. Despite Carlos' repeated digressions from the conjugal bed, then, in David's eyes, they never put his marriage at risk. The extended relationships on which all depended for survival and success in Chicago remained secure and intact.

We might want to see the enabling of, and reinforcement for, Carlos's relationship as merely a reward of patriarchy and male privilege. Yet dynamics of migration complicate the picture. In dismissing the importance of migrants' Chicago actions, Juan Pablo hinted at the multiple understandings of men's sexuality and sexual relationships. These men, whose lives were greatly shaped by their lack of required documents, formed strong attachments to fellow migrants and used (primarily) Mexican markers of status to determine their place within the group hierarchy. The limitations on the men's authority and presence, made real by their unauthorized status - markers of patriarchal privilege in Durango - produced migrants' loyalty and the silence necessary for Carlos to cheat on his wife and for Juan Pablo to claim that men's Chicago actions did not count.

Yet the loyalty fostered through migrant interdependence often ran afoul of patriarchy's assigned responsibilities to family. An example is the relationship of Cara, a widowed Mexican woman in Chicago, and Tadeo, who was married to María, another of Juan Pablo's sisters. They had been going out about six months when Luis, another of Juan Pablo's brothers and brother to María, told me, "he can chingar (fuck) her [Cara] here, but only here-he'll never leave [his wife] María." None of the brothers was happy about Tadeo's cheating ways, but no one ever told his wife, their sister. Nor did they interfere with Tadeo and Cara's relationship. They knew that it would not survive beyond Chicago, despite Tadeo's only feeble investment in his marriage: he only called his wife once - maybe twice - a month and often claimed that he could not send money, though he repeatedly indulged in leisure activities; and on those rare occasions when he did return for a visit - usually because he had lost his job - he brought few gifts. Still, his attachment to his wife and children went unquestioned, and his liaisons forgiven. In the end, Tadeo's expressions of investment, though minimal, were sufficient to confirm his commitment to a relationship that undergirded everyone's Chicago survival. Luis-and-brothers' refusal to see the affair as a significant threat - a tempering of its disruptive potential - reinforced accepted understandings of manhood and patriarchal privilege, and stabilized possibly precarious migrant bonds.

16 Another incident highlighting this same sexual privilege-containment tension occurred long after I had left the restaurant when I popped in during one of my trips home to check on friends' husbands. Everyone, glad to see me, suggested that we get together after The Eatery closed. I agreed and around eleven, met Juan Pablo, Miguel, Kendall, Greenlee, and Greenlee's new boyfriend, Aidan - a smart good-looking thirtysomething Irish American guy unaffiliated with The Eatery, whose dark brown hair was pulled back in a ponytail - at a local tavern. We found a large rectangular table and sat down Juan Pablo, Miguel, and others at one end and Greenlee, Aidan, Carlos, and myself at the other. We ordered drinks, sat back, and relaxed. This, Greenlee told me later, was not the first time that Aidan (her lover of nearly two years) had met or spent time with her Eatery friends. Greenlee and Juan Pablo, who had been an Eatery couple for over a 
year several years before, had established a friendship when their romantic entanglement ended; often when Aidan met Greenlee after work, Juan Pablo joined the two for a drink. According to Greenlee, Juan Pablo appeared to sincerely enjoy Aidan's company and respect - even if he did not like - Greenlee's relationship with him. Carlos, on the other hand, had never participated in any after-work outings with the new pair; while Greenlee and Carlos's relationship had lasted almost as long as Juan Pablo and hers, Carlos always declined any invitation.

ening, however, perhaps due to my presence, Carlos decided to join the festivities. As I talked with people at the table, I - seated next to Carlos - sensed a different attitude from him. He seemed tense, not his usual playful self, despite his animated conversation with Aidan, who was seated across the table next to Greenlee. Initially I dismissed the feeling, but later caught a furtive glance he directed at Greenlee. And when I returned to the table from the bathroom, I saw Carlos's stocking foot massaging Greenlee's thigh. As Greenlee confessed later, Carlos had started his covert assault not long after we sat down. Not wanting to call attention to his actions or make anyone feel uncomfortable -- especially Aidan -- she had instead brushed his foot from her leg and tried to reposition her body beyond his reach. But to no avail : he repeatedly re-maneuvered within his leg's distance, all while he engaged Aidan in a discussion of the sexual availability of U.S., as opposed to Mexican, women.

How should we understand Carlos's lack of respect for Greenlee's relationship with Aidan? His comportment differed, most notably, from that of Juan Pablo, who had also lost Greenlee to Aidan, although unbeknownst to him, to his brother-in-law first. Greenlee had told me several times that Juan Pablo seemed to prioritize his friendship to Aidan over his with her, so much so that when they got together, she frequently felt left out of the conversation. The two men often chatted about women and sex, things from which Juan Pablo presumed that Greenlee would be naturally excluded. Carlos, in contrast, though overtly cordial to Aidan, reacted to Greenlee's new relationship with covert glances across the table and the thigh massage.

Yet, in many ways, both men reacted according to patriarchy's gendered schema. Juan Pablo used his male-to-male relationship with Aidan to discount Greenlee's rejection and to put her in her place, while Carlos articulated Aidan's win in this sexual arena by treating Greenlee as nothing but a sexual object - the perennial whore, a traitor and weak-link, and not under the legitimate protection of a man; and Aidan was likewise denied his status as honorable adult man. We might also see this as acting out in a furtive way Carlo's desire to best a man who in terms of U.S. masculinity -- Aidan's secure job, ability to speak English, education, white privilege, class, and citizenship-had bested him. Also evidenced in Carlos's interactions with Aidan was the competition for female affection underlying male-to-male relationships. By clandestinely touching Greenlee as he conversed nonchalantly with Aidan, Carlos attempted to reclaim her sexually, as his whore, even though his need to reclaim her via under-the-table actions reflected his acknowledgement of official loss. This exchange functioned as the moment for reacquiring the male privileges and prowess lost when Greenlee chose Aidan, and to reaffix, even if only in his own eyes, a better place in the masculine pecking order. Through this struggle, premised on male-male competition and which recognized the exploits and winnings of others, the lines of migrant loyalty were resecured. 


\section{Containing the Exercise of Privilege} use a piece of gossip to analyze an instance of a very different form of containment. According to the rumor, one weekend, Jorge López, himself from Durango, went to a child's birthday party at the Chicago home of his friend, Mateo Santos. Jorge, however, did not attend alone; he brought a special guest. Several weeks later, a videotape of their grandson's party arrived at the Durango house of Mateo's parents. Everyone gathered around to watch. They commented on who had attended, what they were wearing, the food served. One of the sisters recognized Jorge; more importantly, she recognized that the guest on his arm was not his wife-she had remained in Mexico. Oops!

21 By the time I arrived in Durango for fieldwork, the fallout from the Jorge Incident had long subsided. Rumor had it that he ended his relationship with the other woman and returned hurriedly home to his wife and a poorly-paying job. The story, passed on in Durango and Chicago, served as a cautionary reminder of what could happen if patriarchal privilege ran amok and crossed beyond a discreet affair into the realm of family. Not only did it confirm U.S. women's sexuality as predatory (see note 3), it also exposed as myth the notion that the couple was the critical bond to which all others were anchored, since only through the complicity of wives' own brothers and cousins were these betrayals possible. Ironically, this feat was done through technology that Jorge's own labor had bought and paid for.

How are we to understand the power that this incident held and the meaning of its continued circulation? I contend that they reveal the complexity of patriarchy as a social system and, maybe, a key to its resilience -- that it has limits. This story illustrates the consequences of sexual transgressions that were seen to threaten the primacy of the family and the disciplining of its transgressor (Hirsch J. S., et al., 2009). Thus, the affair was acceptable, for it confirmed everyone's "truth" about male sexuality; but its public display was not, for it put Jorge's new relationship on par with his marriage, a threat that keeping of the Jorge Incident alive attempted to quell.

Still, the bonds on which Jorge's non-marital relationship was grounded were already under pressure. As the incident itself and Jorge's hurried return to Mexico suggest, in the logic of modern marriage, the husband's sexual prerogative must be subsumed to family survival, defanged so as to neutralize any threat to the primacy of the family, a threat made visible in the videotape. Indeed, as I have explained here, men's own honor was predicated on their ability to protect family honor and the reputations of female family members-reputations soiled and then repaired, in the case of the Jorge Incident, through his return home and seeming reprioritization of his marital family. However, this family primacy is in the abstract, for the patriarchal privilege that makes ties among men so valuable still reigns - indeed migrant loyalty in Chicago is the product of both conceding those relationships (as sexual privilege) and keeping their threat to marriages contained (nulling the risk to the community). In the end, what we'd expect to be centrifugal pressure on the bonds between men - the affairs and the attendant sullying of family reputations - did not end up weakening either migrant interrelations from which men organized life in Chicago or the marriages that had united them in the first place. 


\section{Conclusion}

In sum, the article shows both the conundrum in which migrants find themselves and the way they resolve it. While we would have expected men to discipline a cheating brother-in-law or cousin or father or friend for acts potentially dishonoring the family's reputation, upholding the honor code, David closed his eyes to what hisbrother-in-law, Carlos, was doing with Greenlee and the implicit disrespect it brought sister Marissa. In fact, these relationships never threatened either migrant interrelationships or patriarchy. Thus, though men's actions in Chicago both chafed at the social and familial bonds that undergirded and sustained them during their stay, they instituted their own regulations that made non-marital liaisons an extension of their position as men and unthreatening to marriages. In other words, migrants found a way to contain the risk that sexual privilege posed to their community while still permitting them to partake in its benefits. They had their cake and ate it too, so to speak. Thus, though men's affairs exerted pressure on the social bonds that sustained migrants in Chicago, they found way to defang this threat-affairs did "not count." Only by recognizing the deep commitment unauthorized migrants make to each other and, importantly, to the survival of the community can we begin to understand the profound social and cultural losses and dislocations that undocumented migration requires.

\section{BIBLIOGRAPHIE}

Cantu Jr., Lionel, Nancy A. Naples and Salvador Vidal-Ortiz (eds.), The Sexuality of Migration: Border Crossings and Mexican Immigrant Men, New York City, New York University Press, 2009.

Cohen, Deborah, Braceros : Migrant Citizens and Transnational Subjects in the Postwar United States and Mexico, Chapel Hill, University of North Carolina Press, 2011.

Cohen, Deborah, Loyalty and Betrayal: Migrants, the State, and the Making of an Affective United States and Mexico, 1940-2000, in progress.

Frazier, Lessie Jo, Salt in the Sand: Memory, Violence, and the Nation-State in Chile, 1890-Present, Politics, History, and Culture Series, Durham, Duke University Press, 2007.

George, Sheba, When Women Come First: Gender and Class in Transnational Migration, Berkeley, University of California Press, 2005.

González-López, Gloria, Erotic Journeys, Mexican Immigrants and Their Sex Lives, Berkeley and London, University of California Press, 2005.

Goldring, Luin and Sailaja Krishnamurti, Organizing the Transnational : Labour, Politics, and Social Change, University of British Columbia, 2008.

Gordillo, Luz María, Mexican Women and the Other Side of Immigration: Engendering Transnational Ties, Austin, University of Texas Press, 2010. 
Hirsh, Jennifer S., A Courtship after Marriage: Sexuality and Love in Mexican Transnational Families, Berkeley, University of California Press, 2003.

Hirsh, Jennifer S., Holly Wardlow, Holly Smith et al., The Secret, Love, Marriage, and HIV, Nashville, Vanderbilt University Press, 2009.

Hondagneu-Sotelo, Pierrette, Gendered Transitions: Mexican Experiences of Immigration, Berkeley, University of California Press, 1994.

Kandiyotti, Deniz, "Women, the state and politics; From empire to nation state: transformation of the woman question in Turkey," In S. Jay Kleinberg (ed.), Retrieving Women's History: Changing Perception of the Role of Women in Politics and Society, Paris, Berg Publishers, 1990 [1988].

Kandiyotti, Deniz, "Identity and its Discontents: Women and the Nation," In Patrick Williams and Laura Cristman (eds.), Colonial Discourse/Postcolonial Theory, New York, Columbia University Press, 1994, p. 376-391.

Kandiyotti, Deniz, "Islam and Patriarchy : A Comparative Perspective," In Sharlene Hesse-Biber, Robin Lydenberg, and Christina Gilmartin (eds.), Feminist Approaches to Theory and Methodology : An Interdisciplinary Reader, New York, Oxford University Press, 1999, p. 219-235.

Knorr, Jacqueline, and Barbara Meier (eds.), Women and Migration: Anthropological Perspectives, New York, Palgrave Macmillan, 2001.

Luibheid, Eithne, and Lionel Cantu Jr. (eds.), Queer Migrations: Sexuality, U.S. Citizenship, and Border Crossings, Minneapolis, University of Minnesota Press, 2005.

Macdonald, Cameron Lynne, Shadow Mothers: Nannies, Au Pairs, and the Micropolitics of Mothering, Berkeley, University of California Press, 2011.

Mahler, Sarah J., "Transnational Relationships: The Struggle to Communicate Across Borders," Identities, vol. 7, $\mathrm{n}^{\circ} 4,2001$, p. 583-619.

Minian, Ana, Undocumented Lives: Mexican Migration to the United States, 1965-1986, in progress.

Parrenas, Rhacel Salazar, Servants of Globalization: Women, Migration, and Domestic Work, Palo Alto, Stanford University Press, 2001.

Segura, Denise A. and Patricia Zavella (eds.), Women and Migration in the U.S.-Mexico Borderlands: A Reader, Durham, Duke University Press, 2007.

Smith, Robert C., Mexican New York: Transnational Lives of New Immigrants, Berkeley, University of California, 2005.

Wilson, Tamar Diana, Women's Migration Networks in Mexico and Beyond, Albuquerque, University of New Mexico Press, PAP/MAP edition, 2009.

\section{NOTES}

1. Migration itself also threatened claims to manhood. When a husband departed, not only could wives fall prey to the advances of other men, they also expanded their realm of authority as they took on husband's former tasks (Cohen 2011).

2. While not integral here, the patriarchal logic that afforded men the right to act on sexual desire dovetailed nicely with attitudes and actions around sex, desire, and commitment of the middle-class U.S. white women with whom they worked (Mahler S. J., 2001). These young women usually acted on their own sexual desires without the 
requirement of commitment. Though most ultimately sought marriage and children, they did not understand engaging in sexual relationships before marriage as inherently foreclosing or enabling these possibilities. They, instead, considered sex an integral part of intimate relationships and not reserved only for ones with marriage potential (González-López G., 2005). Although Eatery women would have likely preferred that their Mexican lovers were not married, conflicts over relationship practices-and not men's marital status per se-usually fueled a break-up.

3. The patriarchal logic that afforded men the right to act on sexual desire dovetailed nicely with attitudes and actions around sex, desire, and commitment of the middleclass U.S. white women with whom they worked (Mahler S. J., 2001). These young women usually acted on their own sexual desires without the requirement of commitment. Though most ultimately sought marriage and children, they did not understand engaging in sexual relationships before marriage as inherently foreclosing or enabling these possibilities. They, instead, considered sex an integral part of intimate relationships and not reserved only for ones with marriage potential (González-López G., 2005). Although Eatery women would have likely preferred that their Mexican lovers were not married, conflicts over relationship practices-and not men's marital status per se-usually fueled a break-up.

\section{RÉSUMÉS}

Cet article étudie les conséquences des relations extraconjugales de migrants mexicains sur les relations sociales au sein d'une communauté de migrants sans-papiers à Chicago, et la façon dont les hommes essaient de limiter cet impact. Mon terrain est The Eatery, un petit restaurant de Chicago où des migrants ou des membres de leurs familles étendues travaillaient et auquel ils étaient tous liés. J'ai observé que les liaisons des hommes n'étaient pas seulement tolérées, elles étaient perçues comme sans importance. Je défends l'idée que cet arrangement confortait à la fois les liaisons et le privilège patriarcal qui les permettait en premier lieu, tout en contenant leurs probables effets négatifs sur les relations sociales entre migrants. Ainsi, il confortait la capacité d'un individu à avoir des relations extraconjugales et il était le moyen de contenir leurs effets déstabilisateurs sur l'ensemble de la communauté migrante. Ce n'est qu'en reconnaissant cet endiguement que nous pouvons commencer à comprendre les dislocations sociales et culturelles plus larges et l'étendue des pertes qui caractérisent la migration illégale.

This article explores the consequences of Mexican migrants' extramarital affairs on social relations within a community of undocumented migrants in Chicago, and the ways men attempt to limit their impact. My fieldsite for this exploration is The Eatery, a small Chicago restaurant in which migrants or their natal or extended family members worked and to which all were anchored. What I found was that men's trysts were not merely tolerated; they were understood to not count. I argue that this arrangement upheld both the affairs and the patriarchal privilege that allowed them in the first place, even as it mitigated their probable negative effects on intermigrants social relations. Thus, it fostered an individual's ability to have extramarital relationships and became the vehicle for containing their destabilizing effects on the entire 
migrant community. Only in recognizing this containment can we begin to understand the larger social and cultural dislocations and array of losses that ground unauthorized migration.

Este artículo explora las consecuencias de relaciones extramaritales de los migrantes mexicanos en las relaciones sociales dentro de una comunidad de inmigrantes indocumentados en Chicago, y las formas en que los hombres tratan de limitar su impacto. Mi terreno de investigación es The Eatery, un pequeño restaurante de Chicago, en el que los migrantes o sus familiares natales o extendidas trabajadas y al que todos estaban anclados. Lo que encontré fue que las citas de los hombres no fueron simplemente toleradas; se las consideraba sin importancia. Sostengo que este arreglo confirmó tanto las relaciones extramaritales y el privilegio patriarcal que les permitió, en primer lugar, aun cuando mitigado sus efectos negativos probables sobre las relaciones sociales entre los migrantes. Así, se fomentó la capacidad de un individuo para tener relaciones extramaritales y se convirtió en el vehículo para contener sus efectos desestabilizadores en toda la comunidad migrante. Sólo en el reconocimiento de esta contención podemos comenzar a entender los trastornos sociales y culturales de mayor tamaño y la variedad de las pérdidas que fundamentan la migración no autorizada.

\section{INDEX}

Mots-clés : privilège patriarcal, migration mexicaine, masculinité, relations sociales entre migrants, Chicago

Palabras claves : privilegio patriarcal, migración mexicana, masculinidad, relaciones sociales entre los migrantes, Chicago

Keywords : patriarchal privilege, Mexican migration, manhood, inter-migrant social relations, Chicago

\section{AUTEUR}

\section{DEBORAH COHEN}

Historian Deborah Cohen (University of Missouri-St. Louis) brings questions of race, gender, imperialism, modernity, and labor to bear on nation-state formation and other political projects. Her first book, the prize-winning Braceros : Migrant Citizens and Transnational Subjects in the Postwar United States and Mexico (University of North Carolina, 2011) does this work by revealing the paradoxes of modernist political economies and the predicaments of transnational subjects in the United States and Mexico; whereas her new solo project, Loyalty and Betrayal, from which this article is drawn, delves more deeply into the intimacies of migratory laboring life as shaped by political economic orders and claims. In addition, she is writing two co-authored monographs with Lessie Jo Frazier (Indiana University) The Global 1968 which explores 1968 as a global phenomenon by looking at the ways that race and class mixing of student movements challenged hierarchical social orders, precipitating violent backlash; and The Romance of Banditry, which uses filmic renditions of Zorro as a window onto the shifting imaginaries of political projects, economic orders, and notions of social justice from the early twentieth century till today. 